\title{
Pengaruh Jenis Pupuk dan Tingkat Arbuskular Mikoriza terhadap Pertumbuhan dan Hasil Jahe (Zingiber officinale)
}

\section{Effects of Manure Kinds and Arbuscular Mycorrhizal Levels to The Growth and Yield of Ginger (Zingiber officinale)}

\author{
Dhimas Taufika Putra $^{1)}$, Samanhudi ${ }^{2)}$, Purwanto $^{2)}$
}

\begin{abstract}
Ginger (Zingiber officinale) is one kind of plants to be processed as traditional medicine, drinks, and spices. the smallest type of ginger that has many benefits as medical plant. Demand for ginger plants growing in the community is increasing. Additions of manure and arbuscular mychorrhizal fungi (AMF) can increase the quality and quantity of ginger. This was conducted to obtain the kinds of manure and levels of AMF to ginger to produce optimum growth and yield. This research used a completely randomized design (CRD) consisting of two treatment factors, namely planting medium and arbuscular mycorrhizal fungi (AMF). Results were analyzed by analysis of variance and if there is a real difference continued DMRT 5\% level. The results showed that the differences in the kinds of manure and the levels of AMF increase growth and yield of ginger. Chicken manure application showed the highest results in the fresh weight of stover plant, dry weight of plant stover, fresh weight of plant rhizomes, and dry weight of the rhizomes. Whereas the additions of AMF 15 grams per plant in zeolite showed the highest results in the number of plant tillers, dry weight of plant stover, fresh weight of plant rhizomes, and dry weight of the rhizomes.
\end{abstract}

Keywords : ginger, manure, AMF

\section{PENDAHULUAN}

Jahe (Zingiber officinale) merupakan salah satu tanaman yang sangat dibutuhkan masyarakat sebagai bahan baku obat tradisional, minuman dan bumbu masak. Data statistik dari BPS (2010) menjelaskan permintaan akan jahe tersebut semakin hari semakin meningkat. Upaya untuk memenuhi banyaknya permintaan tersebut ternyata masih terdapat berbagai hambatan terutama dalam segi kualitas dan juga kuantitasnya. Oleh karena itu, untuk mendapatkan kualitas dan kuantitas jahe lebih baik, dapat dilakukan dengan menambahkan bahan organik berupa pupuk kandang dan cendawan mikoriza arbuskula (CMA).

Pupuk kandang dapat menambah ketersediaan unsur hara bagi tanaman yang dapat diserapnya dari dalam tanah (Sutejo et al. 1990). Pupuk kandang tidak hanya mengandung unsur makro seperti N,P,K, namun juga mengandung unsur mikro seperti $\mathrm{Ca}, \mathrm{Mg}$, $\mathrm{Mn}$ yang dibutuhkan tanaman serta berperan memelihara keseimbangan hara dalam tanah (Andayani dan Sarido 2013). Talanca (2010) menjelaskan bahwa CMA adalah jenis cendawan tanah yang keberadaannya dalam tanah sangat mempunyai manfaat. Hal ini disebabkan karena CMA dapat meningkatkan ketersediaan dan pengambilan unsur fosfor, air, dan nutrisi lainnya, serta untuk pengendalian penyakit yang disebabkan oleh patogen tular tanah.

1) Undergraduation Student of Study Program of Agrotechnology, Faculty of Agriculture University of Sebelas Maret (UNS) in Surakarta.

${ }^{2)}$ Lecturer of Study of Agrotechnology, Faculty of Agriculture University of Sebelas Maret (UNS) in Surakarta.

Contact Author: dhimasbis.tp@gmail.com
Penggunaan pupuk kandang dan CMA diharapkan tidak hanya mampu meningkatkan hasil tanaman secara cepat namun juga mempertahankan kesuburan tanahnya. Keberadaan CMA kurang mendapat perhatian dari masyarakat khususnya petani karena masih maraknya penggunaan pupuk anorganik yang lebih cepat menunjukkan hasilnya dari pada penggunaan CMA. Pupuk anorganik memang membuat tanaman lebih terlihat subur dalam waktu yang singkat namun dapat merusak kesuburan tanah baik secara fisik, kimia, dan biologinya.

\section{METODE PENELITIAN}

Penelitian lapang dilaksanakan bulan November 2013 sampai Juni 2014 di Desa Tamansari, Kecamatan Kerjo, Kabupaten Karanganyar, Jawa Tengah. Penelitian laboratorium dilakukan di Laboratorium Ekologi dan Manajemen Pertumbuhan Tanaman, Laboratorium Biologi Tanah, dan Laboratorium Kimia Tanah Fakultas Pertanian UNS.

Penelitian menggunakan rancangan acak lengkap (RAL) yang terdiri atas dua faktor perlakuan dengan lima kali ulangan sehingga diperoleh 16 kombinasi perlakuan. Faktor pertama adalah media tanam yang terdiri atas 4 macam, yaitu tanah, tanah + pupuk kandang ayam, tanah + pupuk kandang kambing, tanah + pupuk kandang sapi. Faktor kedua adalah CMA yang terdiri atas 4 taraf, yaitu tanpa CMA, CMA 5 gram, CMA 10 gram, CMA 15 gram dalam zeolit per tanaman. Data yang diperoleh dianalisis menggunakan analisis ragam dan apabila terdapat beda nyata dilanjutkan dengan DMRT taraf $5 \%$.

HASIL DAN PEMBAHASAN

Tinggi Tanaman 
Hasil analisis ragam menunjukkan bahwa perbedaan jenis pupuk berpengaruh nyata terhadap tinggi tanaman sedangkan perlakuan perbedaan taraf CMA tidak berpengaruh nyata. Hasil uji lanjut pengaruh perbedaan jenis pupuk terhadap tinggi tanaman disajikan dalam Tabel 1.

Tabel 1. Pengaruh jenis pupuk kandang terhadap tinggi tanaman

\begin{tabular}{ll}
\hline Jenis Pupuk & Tinggi Tanaman $(\mathrm{cm})$ \\
\hline Tanpa pupuk & $35,40 \mathrm{a}$ \\
Pupuk kandang ayam & $51,00 \mathrm{bc}$ \\
Pupuk kandang kambing & $47,20 \mathrm{~b}$ \\
Pupuk kandang sapi & $56,30 \mathrm{c}$ \\
\hline
\end{tabular}

Keterangan: Angka yang diikuti huruf yang sama menunjukkan tidak beda nyata pada uji Duncan taraf 5\%.

Tabel 1 menunjukkan jenis pupuk kandang yang memiliki pengaruh nyata terhadap tinggi tanaman. Tanaman tertinggi diperoleh pada perlakuan pupuk kandang sapi dengan tinggi rata-rata $56,30 \mathrm{~cm}$. Hasil ini tidak berbeda nyata dengan perlakuan pupuk kandang ayam namun berbeda nyata dengan perlakuan pupuk kandang kambing dan tanpa pupuk. Menurut Sutejo et al. (1990), pupuk kandang dianggap sebagai pupuk lengkap karena selain menimbulkan tersedianya unsur-unsur hara bagi tanaman, juga mengembangkan kehidupan mikroorganisme (jasad renik) di dalam tanah.

\section{Jumlah Daun Tanaman}

Hasil analisis ragam menunjukkan bahwa perbedaan jenis pupuk dan taraf CMA tidak berpengaruh nyata terhadap jumlah daun jahe. Dalam penelitian ini daun tanaman yang diberikan pupuk kandang ayam hanya terlihat lebih besar dan hijau daripada perlakuan lainnya. Menurut Sutejo et al. (1990), fungsi utama Nitrogen bagi tanaman yaitu meningkatkan pertumbuhan daun sehingga daun tanaman terlihat lebar dan lebih hijau yang menandakan bahwa tanaman dalam kondisi sehat.

\section{Jumlah Anakan Tanaman}

Hasil analisis ragam menunjukkan bahwa perbedaan jenis pupuk kandang tidak berpengaruh nyata terhadap jumlah anakan jahe, sedangkan perbedaaan taraf CMA berpengaruh nyata. Hasil uji lanjut pengaruh perbedaan taraf mikoriza terhadap jumlah anakan jahe disajikan dalam Tabel 2.
Tabel 2 menunjukkan taraf CMA berpengaruh nyata terhadap rata-rata jumlah anakan jahe. Jumlah rata-rata anakan tertinggi terdapat pada pemberian CMA 15 gram dalam zeolit pertanaman. Rata-rata jumlah anakan ini berbeda nyata dengan tanpa pemberian CMA dan pemberian CMA 5 gram namun tidak berbeda nyata dengan pemberian 10 gram dalam zeolit per tanaman. Hal ini disebabkan karena taraf pemberian CMA yang semakin besar akan menyebabkan infeksi mikoriza pada akar tanaman yang semakin banyak, sehingga penyerapan unsur $P$ lebih optimal. Anakan merupakan salah satu titik tumbuh tanaman jahe yang terdapat pada rimpang yang merupakan tumbuhan muda, sehingga ketersediaan unsur $\mathrm{P}$ sangat dibutuhkan dalam pertumbuhannya. Seperti yang dijelaskan Wahyono (2012), Unsur P sifatnya bergerak dalam tanaman, mudah dipindahkan dari bagian daun yang muda ke titik tumbuh.

\section{Panjang Akar Tanaman}

Hasil analisis ragam menunjukkan bahwa perbedaan jenis pupuk kandang dan taraf CMA tidak berpengaruh nyata terhadap panjang akar tanaman. Lakitan (1993) menambahkan bahwa pada kondisi fisik dan kimia tanah yang optimal, sistem perakaran tanaman sepenuhnya dipengaruhi oleh faktor genetis. Selain itu, menurut Talanca (2010) apabila CMA menginfeksi akar tanaman inang, maka tidak ada bedanya dengan akar-akar yang tidak terinfeksi yaitu tidak terjadi perubahan bentuk dan tetap mempunyai rambut akar. Kolonisasi mioriza pada akar tanaman dapat memperluas bidang serapan hara dengan adanya hifa eksternal yang tumbuh dan berkembang melalui bulu akar. Selanjutmya miselia cendawan CMA dapat tumbuh dan menyebar keluar akar sekitar lebih $9 \mathrm{~cm}$, dengan total panjang hifanya dapat mencapai $54 \mathrm{~m} \mathrm{~g}^{-1}$ tanah.

\section{Berat Segar Brangkasan Tanaman}

Hasil analisis ragam menunjukkan bahwa jenis pupuk berpengaruh nyata terhadap berat segar brangkasan tanaman sedangkan perlakuan perbedaan taraf CMA tidak berpengaruh nyata. Hasil uji lanjut pengaruh perbedaan jenis pupuk terhadap berat segar brangkasan tanaman disajikan dalam Tabel 3.

Tabel 2. Pengaruh taraf CMA terhadap jumlah anakan tanaman

\begin{tabular}{ll}
\hline Cendawan Mikoriza Arbuskula (CMA) & Jumlah Anakan \\
\hline Tanpa CMA & $10,95 \mathrm{a}$ \\
5 gram dalam zeolit per tanaman & $11,00 \mathrm{a}$ \\
10 gram dalam zeolit per tanaman & $12,20 \mathrm{ab}$ \\
15 gram dalam zeolit per tanaman & $14,10 \mathrm{~b}$ \\
\hline
\end{tabular}

Keterangan: Angka yang diikuti huruf yang sama menunjukkan tidak beda nyata pada uji Duncan taraf $5 \%$.

Tabel 3. Pengaruh jenis pupuk kandang terhadap berat segar brangkasan

\begin{tabular}{ll}
\hline Jenis Pupuk Kandang & Berat Segar Brangkasan $(\mathrm{g})$ \\
\hline Tanpa pupuk & $52,28 \mathrm{a}$ \\
Pupuk kandang ayam & $80,38 \mathrm{~b}$ \\
Pupuk kandang kambing & $56,96 \mathrm{a}$ \\
\hline \hline
\end{tabular}


Pupuk kandang sapi 47,46 a

Keterangan: Angka yang diikuti huruf yang sama menunjukkan tidak beda nyata pada uji Duncan taraf $5 \%$.

Tabel 3 menunjukkan jenis pupuk kandang memiliki pengaruh nyata terhadap rata-rata berat segar brangkasan. Hasil penelitian menunjukkan bahwa rata-rata berat segar brangkasan tertinggi terdapat pada tanaman yang diberikan pupuk kandang ayam yaitu sebesar 80,38 gram. Rata-rata berat segar brangkasan ini berbeda nyata dengan perlakuan lainnya. Kandungan nitrogen yang tinggi memberikan pengaruh pada daun yaitu menjadi lebih luas dan lebih hijau. Seperti yang dijelaskan oleh Sahari (2005), bahwa semakin besar luas daun maka semakin tinggi fotosintat yang dihasilkan, sehingga semakin tinggi pula fotosintat yang dipindahkan ke seluruh tubuh tanaman.

\section{Berat Kering Brangkasan Tanaman}

Hasil analisis ragam menunjukkan bahwa perbedaan jenis pupuk kandang dan taraf CMA berpengaruh nyata terhadap berat kering brangkasan tanaman, namun tidak terdapat interaksi antara keduanya. Hasil uji lanjut pengaruh perbedaan jenis pupuk terhadap berat segar brangkasan tanaman disajikan dalam Tabel 4, sedangkan perbedaan taraf mikoriza terhadap berat segar brangkasan tanaman disajikan dalam Tabel 5.

Tabel 4. Pengaruh jenis pupuk kandang terhadap berat kering brangkasan

\begin{tabular}{ll}
\hline Jenis Pupuk Kandang & Berat Segar Brangkasan $(\mathrm{g})$ \\
\hline Tanpa pupuk & $11,03 \mathrm{a}$ \\
Pupuk kandang ayam & $15,34 \mathrm{~b}$ \\
Pupuk kandang kambing & $12,81 \mathrm{a}$ \\
Pupuk kandang sapi & $12,45 \mathrm{a}$ \\
\hline
\end{tabular}

Keterangan: Angka yang diikuti huruf yang sama menunjukkan tidak beda nyata pada uji Duncan taraf $5 \%$.

Tabel 5. Pengaruh taraf CMA terhadap berat kering brangkasan

\begin{tabular}{ll}
\hline Cendawan Mikoriza Arbuskula (CMA) & Berat Kering Brangkasan \\
\hline Tanpa CMA & $10,31 \mathrm{a}$ \\
5 gram dalam zeolit per tanaman & $12,67 \mathrm{~b}$ \\
10 gram dalam zeolit per tanaman & $12,81 \mathrm{~b}$ \\
15 gram dalam zeolit per tanaman & $15,83 \mathrm{C}$ \\
\hline
\end{tabular}

Keterangan: Angka yang diikuti huruf yang sama menunjukkan tidak beda nyata pada uji Duncan taraf $5 \%$.

Tabel 4 menunjukkan perbedaan jenis pupuk kandang memiliki pengaruh nyata terhadap rata-rata berat kering brangkasan. Hasil penelitian menunjukkan bahwa rata-rata berat kering brangkasan tertinggi terdapat pada tanaman yang diberikan pupuk kandang ayam yaitu sebesar 15,34 gram. Rata-rata berat kering brangkasan ini berbeda nyata dengan rata-rata berat kering brangkasan perlakuan lainnya. Hal ini disebebkan karena kandungan unsur $\mathrm{N}, \mathrm{P}$, dan $\mathrm{K}$ yang paling tinggi yang terdapat pada pupuk ayam dibandingkan dengan pupuk lainnya. Latifah dan Arifin (2011) menjelaskan bahwa tanaman banyak memerlukan zat makanan seperti unsur hara $\mathrm{N}$ dan $\mathrm{P}$, dimana perlakuan pupuk kandang ayam yang sudah terdekomposisi dengan cepat memberikan zat makanan esensial seperti unsur hara $\mathrm{N}$ dan $\mathrm{P}$ yang lebih tinggi dari perlakuan pupuk kandang lain.

Tabel 5 menunjukkan perbedaan taraf mikoriza memiliki pengaruh nyata terhadap rata-rata berat kering brangkasan. Hasil penelitian menunjukkan bahwa rata-rata berat kering brangkasan tertinggi terdapat pada tanaman yang diberikan CMA sebanyak 15 gram dalam zeolit yaitu sebesar 15,83 gram. Rata-rata berat kering brangkasan ini berbeda nyata dengan perlakuan lainnya. Hal ini disebabkan karena mikoriza mampu membantu akar tanaman dalam penyerapan unsur-unsur hara yang ada di tanah. Lakitan (1993) menjelaskan bahwa keuntungan dari keberadaan mikoriza adalah meningkatkan serapan fosfat oleh tanaman, walaupun sesungguhnya serapan unsur-unsur hara yang lain juga ikut meningkat.

\section{Berat Segar dan Kering Rimpang Tanaman}

Hasil analisis ragam menunjukkan bahwa jenis pupuk dan taraf mikoriza berpengaruh nyata terhadap berat segar dan kering rimpang, namun tidak terdapat interaksi antara keduanya. Hasil uji lanjut pengaruh jenis pupuk terhadap berat segar dan kering rimpang disajikan dalam Tabel 6 , sedangkan perbedaan taraf CMA terhadap berat segar dan kering rimpang disajikan dalam Tabel 7.

Tabel 6 menunjukkan perbedaan jenis pupuk kandang memiliki pengaruh nyata terhadap rata-rata berat segar dan kering rimpang. Hasil penelitian menunjukkan bahwa rata-rata berat segar dan kering rimpang tertinggi terdapat pada tanaman yang diberikan pupuk kandang ayam yaitu sebesar 66,10 gram dan 16,27 gram. Rata-rata berat segar dan kering rimpang ini berbeda nyata dengan perlakuan lainnya $\mathrm{Hal}$ ini karena pupuk kandang ayam yang mempunyai kandungan unsur hara yang paling tinngi dibandingkan dengan pupuk kandang lainnya, sehingga kebutuhan akan unsur-unsur hara pada tanaman yang diberikan pupuk kandang ayam akan sangat tercukupi untuk pertumbuhan vegetatifnya 
maupun generatifnya. Perlakuan pupuk kandang mempengaruhi bobot kering dan basah rimpang serta produksi rimpang segar saat panen. Wiroatmodjo et al. (1990) menjelaskan penambahan bahan organik sampai batas tertentu dapat meningkatkan produksi dan hasil. sampai batas tertentu ke dalam tanah disamping dapat memperbaiki aerasi tanah juga dapat meningkatkan permeabilitas tanaman sehingga meningkatkan serapan unsur hara. Bahan organik

Tabel 6. Pengaruh jenis pupuk kandang terhadap berat segar dan kering rimpang

\begin{tabular}{lll}
\hline Jenis Pupuk Kandang & Berat Segar Rimpang $(\mathrm{g})$ & Berat Kering Rimpang $(\mathrm{g})$ \\
\hline Tanpa pupuk & $46,22 \mathrm{a}$ & $9,61 \mathrm{a}$ \\
Pupuk kandang ayam & $66,10 \mathrm{~b}$ & $16,27 \mathrm{~b}$ \\
Pupuk kandang kambing & $50,54 \mathrm{a}$ & $7,42 \mathrm{a}$ \\
Pupuk kandang sapi & $40,57 \mathrm{a}$ & $7,73 \mathrm{a}$ \\
\hline
\end{tabular}

Keterangan: Angka yang diikuti huruf yang sama menunjukkan tidak beda nyata pada uji Duncan taraf $5 \%$.

Tabel 7. Pengaruh taraf CMA terhadap berat segar dan kering rimpang

\begin{tabular}{lll}
\hline $\begin{array}{c}\text { Cendawan Mikoriza Arbuskula } \\
\text { (CMA) }\end{array}$ & Berat Segar Rimpang (g) & Berat Kering Rimpang (g) \\
\hline Tanpa CMA & $37,74 \mathrm{a}$ & $6,37 \mathrm{a}$ \\
5 gram dalam zeolit per tanaman & $45,33 \mathrm{ab}$ & $7,94 \mathrm{a}$ \\
10 gram dalam zeolit per tanaman & $56,04 \mathrm{bc}$ & $10,21 \mathrm{a}$ \\
15 gram dalam zeolit per tanaman & $64,32 \mathrm{c}$ & $16,50 \mathrm{~b}$ \\
\hline
\end{tabular}

Keterangan: Angka yang diikuti huruf yang sama menunjukkan tidak beda nyata pada uji Duncan taraf $5 \%$.

Tabel 7 menunjukkan perbedaan taraf CMA memiliki pengaruh nyata terhadap rata-rata berat segar dan kering rimpang. Hasil penelitian menunjukkan bahwa rata-rata berat segar dan kering rimpang tertinggi terdapat pada tanaman yang diberikan mikoriza sebanyak 15 gram dalam zeolit yaitu sebesar 64,32 gram dan 16,50 gram. Hal ini disebabkan karena semakin banyak mikoriza yang diberikan ke tanaman akan semakin banyak pula akar yang terinfeksi mikoriza, sehingga semakin tinggi pula tingkat penyerapan unsur hara dan air yang diperlukan tanaman untuk pertumbuhan vegetatif serta organ-organ generatifnya seperti rimpang yang digunakan untuk menyimpan cadangan makanannya.

\section{Tingkat Infeksi Mikoriza}

Untuk mengetahui infeksi CMA pada penelitian ini, dilakukan analisis infeksi mikoriza dengan metode pengecatan akar. Hasil analisis infeksi CMA disajikan pada Gambar 1.

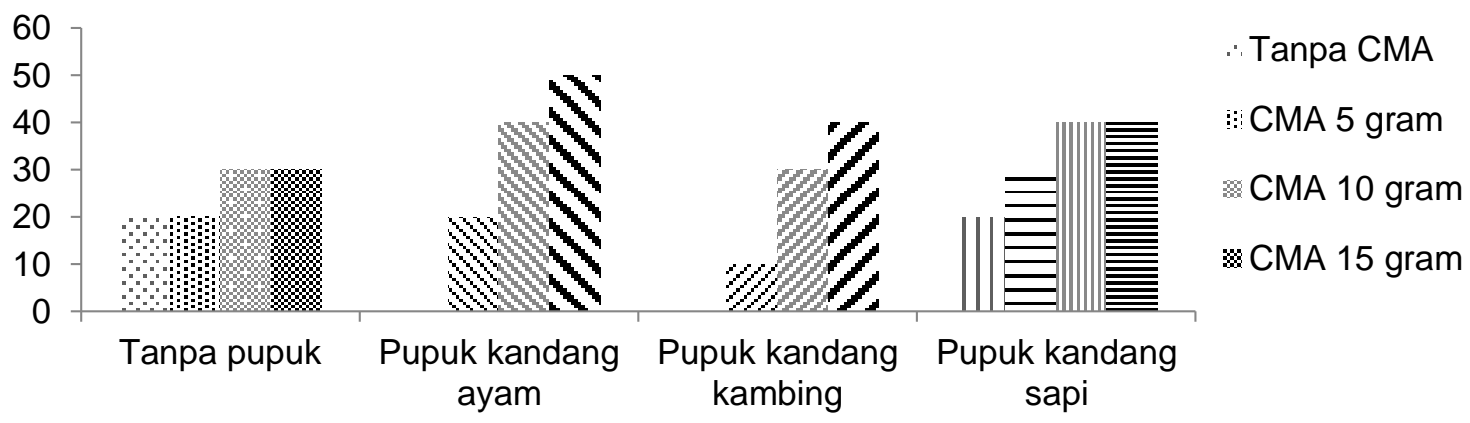

Gambar 1. Persentasi infeksi CMA pada akar tanaman jahe

Dari hasil analisis infeksi CMA yang telah dilakukan, prosentase infeksi CMA paling tinggi hanya $50 \%$ yaitu terdapat pada tanaman yang diberikan kombinasi antara pupuk kandang ayam dan CMA 15 gram dalam zeolit, sehingga dapat dikatakan bahwa rata-rata infeksi CMA tersebut rendah. Rendahnya tingkat infeksi CMA ini disebabkan karena beberapa fakor, salah satunya karena kurang optimalnya kerja CMA dalam menginfeksi tanaman akibat perbedaan ekosistem CMA tersebut sebelumnya. Hal ini sesuai dengan pendapat Sinarmata (2007) bahwa inokulasi mikoriza yang berasal dari suatu ekosistem jika digunakan kembali pada ekosistem yang bersangkutan akan lebih adaptif sehingga interaksi yang terjadi antara mikoiza dengan perakaran tanaman inang menjadi lebih optimal.

\section{KESIMPULAN DAN SARAN}

\section{Kesimpulan}

Kesimpulan yang dapat diambil dari hasil penelitian adalah:

1. Pemberian pupuk kandang ayam mampu meningkatkan pertumbuhan dan hasil jahe, yaitu meningkatkan berat segar brangkasan, berat kering brangkasan, berat segar rimpang, dan berat kering rimpang. 
2. Pemberian CMA dengan taraf 15 gram dalam zeolit per tanaman mampu meningkatkan pertumbuhan dan hasil jahe yaitu meningkatkan

\section{Saran}

Saran yang dapat diberikan untuk penelitian ini adalah perlu adanya penelitian lebih lanjut mengenai pemanfaatan jenis pupuk kandang yang disertai rentang dosis yang lebih bervariasi untuk mendapatkan hasil yang paling optimal dalam peningkatan hasil budidaya jahe.

\section{DAFTAR PUSTAKA}

Andayani, Sarido L. 2013. Uji empat jenis pupuk kandang terhadap pertumbuhan dan hasil tanaman cabai keriting (Capsicum annum L.). J Agrifor 12(1) : 22-29.

Badan Pusat Statistik (BPS). 2010. Karanganyar dalam angka 2010. Karanganyar (ID): Badan Pusat Statistik Kabupaten Karanganyar.

Indriani NP, Mansyur, Susilawati I, Khairani L. 2006. Pengaruh pemberian bahan organik, mikoriza, dan batuan fosfat terhadap produksi, serapan fosfor pada tanaman kudzu tropika (Pueraria Phaseoloides Benth ). J IImu Ternak 6(2) : 158162.

Lakitan B. 1993. Dasar-dasar fisiologi tumbuhan. Jakarta (ID): Raja Grafindo Persada. jumlah anakan tanaman, berat kering brangkasan, berat segar rimpang, dan berat kering rimpang.

Latifah E, Arifin Z. 2011. Pengaruh pemberian pupuk organik terhadap pertumbuhan dan hasil jahe. Balai Pengkajian Teknologi Pertanian Jawa Timur.

Sahari P. 2005. Pengaruh jenis dan dosis pupuk kandang terhadap pertumbuhan dan hasil tanaman krokot landa (Talinum triagulare Willd.). Surakarta (ID). Fakultas Pertanian Universitas Sebelas Maret.

Sutejo, Mulyadi M, Kartasapoetra AD. 1990. Pupuk dan cara pemupukan. Jakarta (ID): Rineka Cipta.

Talanca H. 2010. Status cendawan mikoriza vesikular-arbuskular pada tanaman. Prosiding pekan serealia nasional. Maros 2010. Balai Penelitian Tanaman Serealia Sulawesi Selatan.

Wahyono EH, Sudarno N, Digdo AA, Wijayanto A. 2012. Pertanian alami: bio-starter, Composting dan pestisida alami. Bogor (ID): Yapeka.

Wiroatmodjo. 1990. Pengaruh pupuk kandang terhadap pertumbuhan dan hasil jahe (Zingiber officinale rose.) jenis badak serta periode kritis jahe terhadap kompetisi gulma. Buletin Agronomi 11(3). 